\title{
Dietary modifications achieved successful resolution of symptoms of gastroparesis diagnosed by demonstrating gastric food retention after overnight fasting in diabetic dialysis patients: two case reports with literature review
}

Eriko Eguchi

\begin{abstract}
Background: Gastroparesis is frequently overlooked and difficult to treat. The diagnosis of gastroparesis requires standard upper gastrointestinal endoscopy to exclude gastric outlet obstruction and objective evidence demonstrating delayed gastric emptying. However, none of the internationally recommended methods for measuring gastric emptying including scintigraphy are covered by the Japanese health insurance system. Limitations in the diagnosis might be related to the disease being overlooked in Japan. Meanwhile, presence of retained food in the stomach after overnight fasting without obstruction is classically known to be suggestive of gastroparesis. Some recent reports have considered gastric food retention after an overnight fasting equivalent to delayed gastric emptying.
\end{abstract}

Case presentation: Two diabetic dialysis patients presented with nausea, vomiting, and oral feeding intolerance in the absence of mechanical obstruction. Abdominal computed tomography, upper gastrointestinal endoscopy, and ultrasonography demonstrated gastric food retention after overnight fasting. The findings led to the diagnosis of gastroparesis. Appropriate dietary modifications alone successfully relieved the symptoms despite persistent delayed gastric emptying.

Conclusions: Demonstrating retained food residue after fasting for sufficient duration might be a diagnostic alternative. Dietary modifications alone provided significant clinical benefits. Possible approaches for the diagnosis and treatment of gastroparesis in Japan should be investigated.

Keywords: Gastroparesis, Delayed gastric emptying, Gastric food residue, Diet modifications, Diabetes, Ultrasonography

Correspondence: rmqpy991@yahoo.co.jp

Department of Internal Medicine, Osaka Roudou Eisei Center Daiichi Hospital,

6-2-2, Mitejima, Nishiyodogawa-ku, Osaka-City, Osaka 555-0012, Japan

C C The Author(s). 2020 Open Access This article is licensed under a Creative Commons Attribution 4.0 International License, which permits use, sharing, adaptation, distribution and reproduction in any medium or format, as long as you give appropriate credit to the original author(s) and the source, provide a link to the Creative Commons licence, and indicate if changes were made. The images or other third party material in this article are included in the article's Creative Commons licence, unless indicated otherwise in a credit line to the material. If material is not included in the article's Creative Commons licence and your intended use is not permitted by statutory regulation or exceeds the permitted use, you will need to obtain permission directly from the copyright holder. To view a copy of this licence, visit http://creativecommons.org/licenses/by/4.0/. The Creative Commons Public Domain Dedication waiver (http://creativecommons.org/publicdomain/zero/1.0/) applies to the data made available in this article, unless otherwise stated in a credit line to the data. 


\section{Background}

Gastroparesis is defined as a syndrome of objectively delayed gastric emptying in the absence of mechanical obstruction and cardinal symptoms including early satiety, postprandial fullness, nausea, vomiting, bloating, and upper abdominal pain [1]. In tertiary referral settings, gastroparesis can be classified into three primary types, namely idiopathic (36\%), diabetic (29\%), and postsurgical (13\%) [1]. Other possible causes of gastroparesis include medication, Parkinson's disease, collagen vascular disorders, thyroid dysfunction, and chronic renal insufficiency [2]. Gastroparesis significantly impacts quality of life, as it increases healthcare costs and is associated with morbidity and mortality [3-5]. The guideline developed by American College of Gastroenterology presents recommendations for the evaluation and management of patients with gastroparesis [1].

Patients with gastroparesis frequently remain undiagnosed [6]. The diagnosis of gastroparesis requires standard upper gastrointestinal (GI) endoscopy to exclude gastric outlet obstruction and objective evidence demonstrating delayed gastric emptying [1]. The three recommended methods for measuring gastric emptying include scintigraphy, wireless motility capsule, and carbon breath testing. However, none of them are covered by the Japanese health insurance system. Limitations in the diagnosis might be related to the disease being overlooked or even neglected in Japan.

There has been a point of view considering gastric food retention after an overnight fasting equivalent to delayed gastric emptying as with recent reports [2, 7-9]. Thus, demonstrating retained food residue after sufficient duration of fasting might be an alternative to classic gastric emptying studies. Possible approaches include abdominal computed tomography (CT), upper GI endoscopy, and ultrasonography (US). Among them, US seems to be the most feasible approach due to its easy accessibility, relatively low cost, lack of radiation exposure, and noninvasiveness [10].

The first line of treatment includes restoration of fluids and electrolyte, dietary modifications, and optimization of glycemic control in diabetics [1]. Subsequently, pharmacological therapy using prokinetic agents and/or anti-emetics is considered. For patients with refractory symptoms, second-line approaches include feeding jejunostomy and decompressive gastrostomy. Gastric electrical stimulation has not been approved in Japan. While the definition of gastroparesis focuses on impaired gastric emptying, many pharmacological agents including prokinetics and surgical procedures designed to accelerate gastric emptying have shown disappointing results in randomized controlled studies [11, 12]. The limited efficacy of available therapies often leads to frustration of patients and physicians.
The present report describes two diabetic patients on hemodialysis diagnosed with gastroparesis by demonstrating gastric food retention after overnight fasting with abdominal CT, upper GI endoscopy, and US. Dietary modifications alone successfully relieved their symptoms despite persistent delayed gastric emptying.

\section{Case presentations}

\section{Case 1}

A 74-year-old woman with type 2 diabetes requiring insulin therapy and with a 15-year history of hemodialysis was admitted to our long-term care hospital. Her medical history was notable for a left frontal lobe intracerebral hemorrhage that mildly affected the right side of the body 2 years ago. The medical history also revealed laparoscopic sigmoid colon cancer resection 10 years ago and history of arterioscleroses such as ischemic heart disease, peripheral artery disease, and internal carotid artery stenosis for 15 years, which required stent replacement for each disease entity. Five days after admission, $50 \mathrm{mg}$ sodium ferrous citrate per day was started to improve anemia associated with relative iron deficiency (hemoglobin $9.0 \mathrm{~g} / \mathrm{dL}$, transferrin saturation 0.14 , ferritin $135 \mathrm{ng} / \mathrm{mL}$ ) [13]. As a therapeutic diet, a diabetic meal containing moderate amounts of fat was provided. The amount of fiber in every meal prepared in the hospital was generally lower than that in usual meals due to the nature of the institution handling elderly patients.

Ten days after admission, the patient suddenly developed nausea and vomiting. The vomitus was darkcolored and the amount was approximately $2 \mathrm{l}$ in $3 \mathrm{~h}$. She was transferred to the Acute Care Hospital for the investigation of gastrointestinal bleeding. Her hemodynamic condition was stable (blood pressure 153/ $67 \mathrm{mmHg}$ and a regular pulse rate of 74 beats/min). Upper GI endoscopy revealed no apparent evidence of bleeding except an insignificant gastric angiodysplasia, which was subsequently treated with argon plasma coagulation. She returned to our hospital after successful resumption of oral feeding. The cause of nausea and vomiting was not identified at that time.

Approximately 2 months later, nausea and vomiting recurred along with anorexia. Constipation was controlled with laxatives. Provision of chopped food resulted in no improvement. The symptoms progressively worsened along with oral feeding intolerance and darkcolored vomit in the course of 5 days. Abdominal CT showed a markedly distended stomach despite fasting for $16 \mathrm{~h}$ (Fig. 1a). The intraluminal material was partly hyperdense. Upper GI endoscopy revealed a large amount of fluid and food residue in the stomach without significant bleeding or mechanical obstruction (Fig. 1b). On the basis of the endoscopic findings, the gastric hyperdense contents on CT were interpreted as residual 

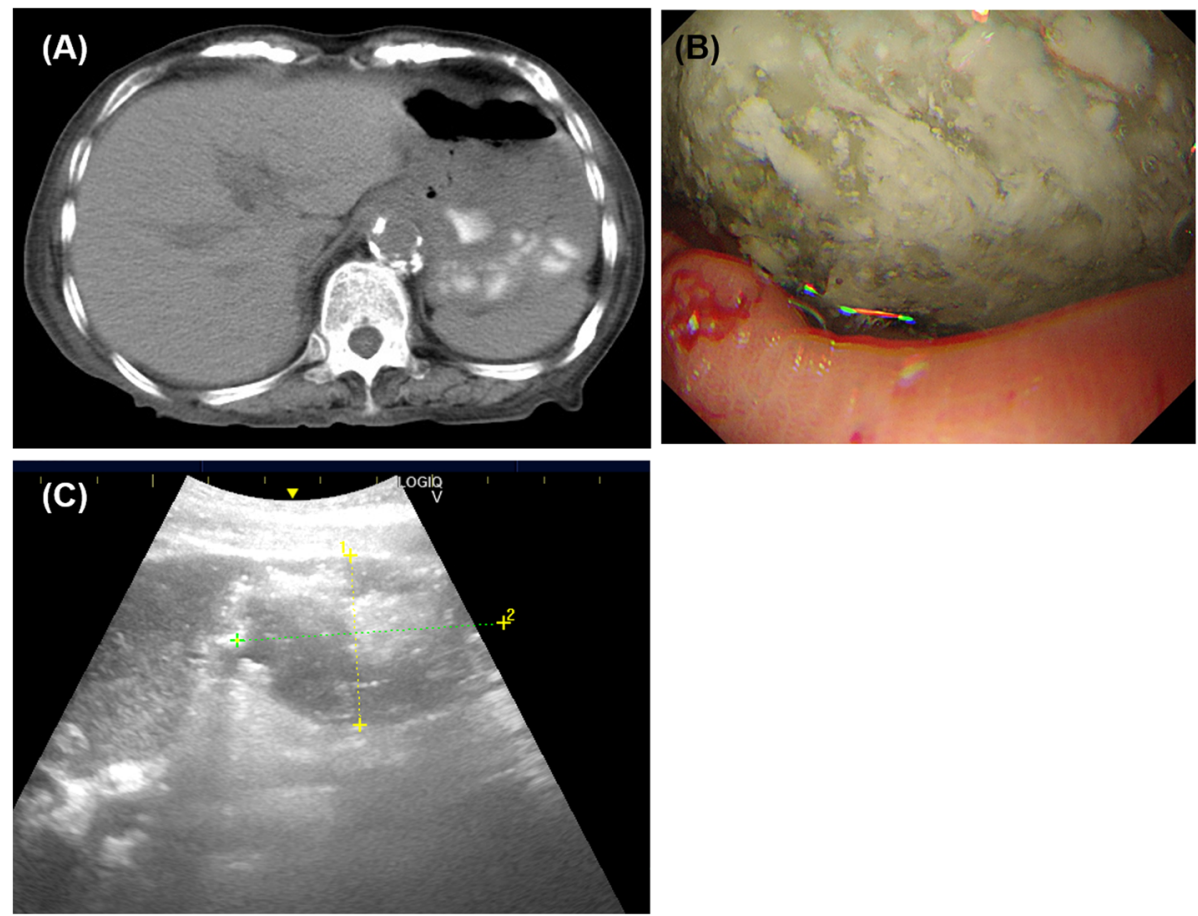

Fig. 1 Images of the stomach in the present case 1. a Computed tomography scan of the abdomen shows a distended stomach with highattenuation material. $\mathbf{b}$ Upper gastrointestinal endoscopy shows a large amount of food residue. $\mathbf{c}$ Sonographic image of the stomach shows a distended stomach with solid gastric contents. All images were obtained after overnight fasting

medications including sodium ferrous citrate [14]. The aforementioned findings and the clinical course were compatible with gastroparesis. Serum albumin concentration was $2.3 \mathrm{mg} / \mathrm{dL}$. The dietary modifications were performed, including small and frequent meals, soft and well-cooked foods, reduced fat and fiber intake, and avoidance of lying down after meals for at least $30 \mathrm{~min}$ $[1,2,15,16]$. Specifically, half a portion of "low residue diet," a type of therapeutic diet prepared in the hospital containing reduced fat content less than $20 \mathrm{~g}$ a day and lower amount of fiber than other types of meals, less than $10 \mathrm{~g}$ a day, was provided three times daily, combined with liquid nutritional supplements as snacks twice a day. Eating frequency added up to five times a day. Soon after the initiation of dietary management, relief of symptoms and sufficient oral intake were achieved. Subsequently, transabdominal US of the stomach was performed. The method is described in detail in the following section. Imaging revealed a distended stomach and solid gastric contents even $14 \mathrm{~h}$ after the last meal (Fig. 1c). These findings suggested highly delayed gastric emptying despite the lack of clinical symptoms. Serum albumin levels slightly increased (2.6-2.8 $\mathrm{mg} / \mathrm{dL}$ ).

Several months later, meal frequency was reduced to half a portion of "low residue diet" three times daily and a package of liquid nutritional supplement at the same time. The patient had an uneventful course without symptoms of gastroparesis.

\section{Case 2}

An 82-year-old diabetic woman undergoing maintenance hemodialysis was hospitalized at our long-term care hospital for 6 years prior to the author's arrival at the hospital. Her medical history included initiation of dialysis 10 years ago and right breast cancer surgery with adjuvant tamoxifen $40 \mathrm{mg}$ daily 2 years ago. The patient had received $10 \mathrm{mg}$ of domperidone twice daily for occasional nausea and vomiting since before hospitalization. Two months after the author's assignment, evocalcet was initiated for secondary hyperparathyroidism.

Approximately 1 year later, persistent nausea and frequent vomiting worsened along with oral feeding intolerance in the course of 2 weeks. Constipation was controlled with laxatives. The symptoms worsened after or even during eating and temporarily ameliorated after vomiting. Upper GI endoscopy showed no remarkable findings 2 months ago. The symptoms and the absence of mechanical obstruction raised a suspicion of gastroparesis partly due to the recent experience with case 1 . Serum albumin concentration was $2.6 \mathrm{mg} / \mathrm{dL}$. A regular portion of "low residue diet" was prescribed three times a day. However, it provided no relief from the symptoms. Subsequently, a reduction in meal size from 
regular portion to half a portion, addition of liquid nutritional supplements as snacks twice daily, and avoidance of lying down after meals for at least $30 \mathrm{~min}$ were prescribed as with case 1, resulting in rapid improvement in symptoms. Domperidone was discontinued without worsening of symptoms. Transabdominal US of the stomach revealed findings almost identical to case 1. A distended stomach and solid contents after $14 \mathrm{~h}$ of fasting suggested highly delayed gastric emptying despite relief from the symptoms. Serum albumin levels increased $(3.2-3.5 \mathrm{mg} / \mathrm{dL})$. Later, meal frequency was successfully reduced to half a portion of "low residue diet" three times daily and a package of liquid nutritional supplement at the same time.

\section{Specific method of transabdominal US of the stomach}

On the evening of the day before the examination (at approximately 18:00 $\mathrm{PM}$ ), patients had a meal consisting of half a portion of "low residue diet," a type of therapeutic diet in our hospital containing reduced fiber and fat content. After overnight fasting for approximately $14 \mathrm{~h}$, gastric US examinations were performed at 8:30 AM following the standardized gastric scanning protocol described by Perlas et al. [17, 18].

Patients were scanned in the supine position and subsequently in the right lateral decubitus position. A lowfrequency $5 \mathrm{MHz}$ curvilinear array probe was used with the GE LOGIQ eV2 ultrasound system (GE Healthcare ${ }^{\mathrm{Tm}}$, Wauwatosa, WI, USA). The transducer was placed in the sagittal plane in the epigastric region. The gastric body was scanned by moving the transducer from right to left to obtain general qualitative information about the gastric cavity and its content. Subsequently, a crosssectional view of the antrum was obtained in the parasagittal plane just to the right of the midline. Landmarks such as the left lobe of the liver anteriorly, the head of the pancreas posteriorly, and the inferior vena cava posterior to the pancreas were used to obtain reproducible results. A qualitative assessment of the antrum was performed in this view. The stomach was considered empty if the antrum appeared flat with juxtaposition of anterior and posterior walls. The antrum was regarded as containing fluid when distended walls and hypoechoic content were demonstrated. The antrum was regarded as containing solid when the distended cavity had hyperechoic and inhomogeneous content, typically described as "frosted-glass appearance."

\section{Discussion and conclusions}

Presence of retained food in the stomach after overnight fasting without obstruction is classically known to be suggestive of gastroparesis [2, 7]. A previous study showed a close association between retained gastric food residue and delays in gastric emptying [7]. In the aforementioned study, $25 \%$ of the patients with delayed gastric emptying diagnosed with scintigraphy exhibited food retention on endoscopy and $75 \%$ of the patients with retained food exhibited delayed gastric emptying. These findings suggest that detection of gastric food retention is a useful surrogate marker of delayed gastric emptying despite not being particularly sensitive. The partial inconsistency between food retention observed on endoscopy and delayed gastric emptying observed on scintigraphy might be associated with the differences in meals consumed prior to the tests and the time intervals from the last meal to testing. Upper GI endoscopy is usually conducted after fasting for 6 or more hours following ingestion of a preferably digestible meal. Scintigraphy for the evaluation of gastric emptying is performed immediately after ingestion of a highly digestive meal and at $1 \mathrm{~h}, 2 \mathrm{~h}$, and $4 \mathrm{~h}$ after the ingestion of the meal $[1,2,19]$.

Current studies have demonstrated the utility of US for qualitative and quantitative evaluation of gastric content in the standardized protocol $[17,18]$. The findings have recently emerged from the field of the anesthesiology requiring methods for assessing aspiration risk. US can determine the nature of gastric content (empty, clear fluid, or thick fluid/solid) based on the sonographic appearance. Solid content carrying a high aspiration risk is virtually equivalent to gastric food residue. Considering the low sensitivity of endoscopic gastric food retention and the invasive nature of endoscopy, repeated US examinations are beneficial in increasing the probability of detection of gastric food residue in patients suspected of gastroparesis in the absence of endoscopic gastric food retention. Sonographic study in case 2 of the present report actually showed solid gastric content despite the absence of food retention in a previous upper GI endoscopy. Persistent delayed gastric emptying despite relief from the symptoms in the present cases is consistent with the incomplete correlation between symptom improvement and acceleration of gastric emptying [2, 11, 12, 20, 21].

Dietary modifications are the cornerstone of treatment for gastroparesis $[1,2]$. Small and frequent meals containing low fiber and low fat content are recommended $[1,2,15,16]$. As gastric emptying of liquids is often preserved in gastroparesis, increasing the liquid nutrient component of a meal is effective. A recent study showed the efficacy of diets with small particle size [22]. However, practicing appropriate nutritional management might be accompanied with some difficulties including an increased workload associated with meal preparation and reluctance of patients to adopt an unusual eating habit, especially in case of outpatients with mild symptoms [23]. Even within hospitals, meal providing systems and hospital staff might be unable to handle frequent 
meal preparation efficiently, as experienced by the author. Achieving successful dietary modifications demands a greater understanding and cooperation from patients and the healthcare staff compared to usual diets consisted of three meals a day.

The disease concept of gastroparesis does not seem to be widely known in Japan. The case 1 from the present report was never suspected to have gastroparesis by the concerned doctors. Hence, considering the possibility of gastroparesis might be the most important determining factor for the diagnosis of gastroparesis in Japan despite significant limitations of diagnosing tests. A lack of correct diagnosis leads to inappropriate management. Presumably, promising dietary modifications are not adopted without the diagnosis of gastroparesis due to their inconvenience. Anti-emetics and prokinetics might be easily prescribed for nausea and vomiting without the diagnosis of gastroparesis, despite the problems associated with these drugs. Facile induction of long-term parenteral nutrition related to undiagnosed gastroparesis is also an important concern, especially in latent bedridden patients in long-term care hospitals. The present cases could have followed such a clinical course.

In conclusion, demonstrating retained food residue after fasting for sufficient duration might be a diagnostic alternative. Dietary modifications alone provided significant clinical benefits. Possible approaches for the diagnosis and treatment of gastroparesis in Japan should be investigated.

\section{Literature review}

(Epidemiology, pathophysiology, and management of gastroparesis and the similarities to functional dyspepsia)

The true prevalence of gastroparesis in the community is unknown. Previous studies showed that definite gastroparesis, defined as delayed gastric emptying demonstrated by standard scintigraphy and typical symptoms for more than 3 months, had a prevalence of 24.2 per 100,000 inhabitants, and an incidence 6.3 per 100,000 persons per year for the years 1996-2006 in Olmsted County, Minnesota [5]. The cumulative proportions developing gastroparesis were $5.2 \%$ in type $1 \mathrm{DM}, 1.0 \%$ in type $2 \mathrm{DM}$, and $0.2 \%$ in controls [24]. There might be many subjects with gastroparesis remaining undiagnosed in the studies, as scintigraphy was not performed in a large group of patients with gastroparesis-like symptoms. On the basis of predictive models, one study estimated that gastroparesis might affect up to $1.8 \%$ of the general population [6]. Moreover, the increasing prevalence of type 2 diabetes might lead to larger numbers of patients with diabetic gastroparesis.

Normal gastric emptying results from the integration of tonic contractions of the proximal stomach, phasic contractions of the antrum, and the inhibitory forces of pyloric and duodenal contractions [25]. These complex phenomena require cooperation between smooth muscle, enteric and autonomic nerves, and specialized pacemaker cells known as the interstitial cells of Cajal. Delayed gastric emptying is derived from disruptions of the mechanisms.

The risk of developing gastroparesis increases with female gender, long-term hyperglycemia, and vagus nerve injury $[1,2,5,26]$. Female gender is more susceptible to developing gastroparesis compared to males in an approximate 4:1 ratio. Possible explanations for this gender difference include an intrinsically slower stomach in females, elevated levels of sex steroid hormones, loss of neuronal nitric oxide expression, and altered serotonergic signaling [27]. Long-term hyperglycemia leads to abnormalities in regulation of gastric motility and results in diabetic gastroparesis. Proposed mechanisms include vagal dysfunction, interstitial cells of Cajal network disturbances, loss of neural nitric oxide synthase expression in the myenteric plexus, and oxidative stress $[28,29]$. Vagus nerve injury usually results from surgical procedures including fundoplication, lung or heart transplantation, esophageal, gastric, and bariatric surgery $[1,30]$. Radiofrequency catheter ablation for atrial fibrillation is another possible cause $[8,9]$.

Pharmacological treatment of gastroparesis usually involves prokinetic agents such as metoclopramide and domperidone despite poor correlation between gastric emptying and severity of gastric symptoms $[1,2,20,21]$. Erythromycin has been occasionally used off-label in anticipation of a prokinetic effect $[1,2]$.

Enteral nutrition needs to be considered for gastroparesis patients lacking adequate oral feeding $[1,2,31]$. Parenteral nutrition is generally not needed in terms of etiology. Temporary feeding access can be achieved by insertion of a nasojejunal tube. For long-term feeding, percutaneous endoscopic gastrostomy or surgical jejunostomy followed by placement of a gastrostomyjejunostomy tube or a jejunostomy tube is preferred.

There is a significant overlap between idiopathic gastroparesis and functional dyspepsia in terms of symptoms and underlying physiological disturbances of stomach function [1,32]. Abdominal pain or discomfort typically is the predominant symptom in functional dyspepsia, in contrast to predominance of nausea, vomiting, early satiety, and bloating in gastroparesis. However, making a definite distinction between gastroparesis and functional dyspepsia based on symptoms is frequently difficult. Therefore, measurement of gastric emptying is recommended before treatment. In functional dyspepsia, acid suppressive therapy, Helicobacter pylori eradication, prokinetic agents, and neuromodulators can be applied [33]. No standardized nutritional guidelines for 
functional dyspepsia are available presumably due to the heterogeneous nature of functional dyspepsia [34].

The correlation between gastric emptying and symptom severity is generally poor, as with the correlation between symptom improvement and acceleration of gastric emptying [1, 2, 11, 12, 20, 21]. Recent studies demonstrated that coexisting anxiety and depression correlate with the perceived severity of gastroparesis symptoms [23, 35]. Physiologic testing in patients with gastroparesis suggested that mechanisms other than emptying, such as impaired accommodation and hypersensitivity to gastric distension, contribute to symptoms of gastroparesis [36]. The findings are reminiscent of findings in patients with functional dyspepsia. Gastric accommodation is a vagally mediated reflex following ingestion of a meal, which is associated with reduction in gastric tone along with an increase in gastric volume and gastric compliance [37]. The proposed mechanisms behind hypersensitivity to gastric distension include genetic factors, inflammation, central and peripheral dysregulation, and emotional factors [38]. Considering these recent findings, impaired gastric emptying remaining the defining endophenotype of gastroparesis is not sufficient to explain the complex symptoms and should not be the sole target of therapeutic interventions $[11,12]$.

\section{Gastroparesis among patients with end-stage kidney disease}

Delayed gastric emptying is common in patients with chronic renal failure regardless of cause [39-43]. One study demonstrated that over $30 \%$ of patients on hemodialysis have significantly prolonged gastric emptying time [39]. The precise etiology of this dysfunction remains unclear. Possible explanations include uremia-induced neuropathy, electrolyte disturbance, vitamin D deficiency, metabolic acidosis, and anemia [41, 42].

Previous studies showed conflicting results regarding the relationship between delayed gastric emptying and gastrointestinal symptoms in patients with end-stage renal disease (Table 1). Several studies have found associations between delayed gastric emptying and dyspeptic symptoms in end-stage renal disease patients [40-42, 44]. In other studies, no correlation was found between gastric emptying and symptoms [45-47]. Some studies showed that delay in gastric emptying correlated with low serum albumin, a surrogate of malnutrition [39, 41, $48,49]$. As there are only a limited number of studies with a small number of subjects, further investigation is needed.

Two studies involving short-term follow-up with small numbers of subjects showed increase in plasma or serum albumin concentration following prokinetic therapy in dialysis patients with delayed gastric emptying $[48,50]$.
Table 1 Relationship between delayed gastric emptying and gastrointestinal symptoms in end-stage renal disease patients

\begin{tabular}{|c|c|c|}
\hline Reference & $\begin{array}{l}\text { Assessment of } \\
\text { gastric emptying }\end{array}$ & Outcome \\
\hline [40] & $\begin{array}{l}\text { 13C-octanoic acid breath } \\
\text { testing }\end{array}$ & $\begin{array}{l}\text { Delayed gastric emptying } \\
\text { was associated with dyspepsia. }\end{array}$ \\
\hline [41] & $\begin{array}{l}\text { 13C-octanoic acid } \\
\text { breath testing }\end{array}$ & $\begin{array}{l}\text { Delayed gastric emptying was } \\
\text { associated with dyspepsia. }\end{array}$ \\
\hline [42] & $\begin{array}{l}\text { 13C-octanoic acid breath } \\
\text { testing and } \\
\text { electrogastrographs }\end{array}$ & $\begin{array}{l}\text { Delayed gastric emptying was } \\
\text { associated with dyspepsia in } \\
\text { patients with abnormal } \\
\text { electrogastrographs. }\end{array}$ \\
\hline [43] & ultrasonography & $\begin{array}{l}\text { Delayed gastric emptying was } \\
\text { associated with dyspepsia in } \\
\text { patients with autonomic } \\
\text { neuropathy. }\end{array}$ \\
\hline [44] & Radionuclide technique & No association \\
\hline [45] & Radionuclide technique & No association \\
\hline [46] & Radionuclide technique & No association \\
\hline
\end{tabular}

There is no evidence that patients with end-stage renal disease are at increased risk of adverse effects of prokinetic agents $[51,52]$. However, given potential severe adverse effects, use of the agents should be assessed on a case-by-case basis [51, 53, 54].

A literature search revealed no reports on the effectiveness of dietary management alone in patients with gastroparesis and renal insufficiency. Sporadic reports have shown successful results from different approaches such as gastric electrical stimulation and newer antiemetics [55-57]. These options are not available in Japan.

\section{Abbreviations \\ CT: Computed tomography; Gl: Gastrointestinal; US: Ultrasonography}

\section{Acknowledgements}

Not applicable.

Author's contributions

EE is the corresponding author and wrote the whole manuscript. The author read and approved the final manuscript.

Funding

Not applicable

Availability of data and materials

The data and materials were all included in the manuscript.

Ethics approval and consent to participate

According to the Ethical Guidelines for Medical and Health Research involving Human Subjects in Japan, ethical approval is not required for case reports.

Consent for publication

Written informed consent was obtained from the son of the patient for the publication of this case report and any accompanying test results.

Competing interests

The author declares no competing interests. 
Received: 30 July 2020 Accepted: 30 November 2020 Published online: 07 December 2020

\section{References}

1. Camilleri M, Parkman HP, Shafi MA, Abell TL, Gerson L. Clinical guideline: management of gastroparesis. Am J Gastroenterol. 2013;108(1):18-37. https://doi.org/10.1038/ajg.2012.373.

2. Parkman HP, Hasler WL, Fisher RS. American Gastroenterological Association Technical Review on the Diagnosis and Treatment of Gastroparesis. Gastroenterology. 2004;127(5):1592-622. https://doi.org/10.1053/j.gastro. 2004.09.055.

3. Talley NJ, Young L, Bytzer P, et al. Impact of chronic gastrointestinal symptoms in diabetes mellitus on health-related quality of life. Am J Gastroenterol. 2001;96(1):71-6 PMID: 11197290.

4. Hyett B, Martinez FJ, Gill BM, et al. Delayed radionucleotide gastric emptying studies predict morbidity in diabetics with symptoms of gastroparesis. Gastroenterology. 2009;137(2):445-52. https://doi.org/10.1053/ j.gastro.2009.04.055.

5. Jung HK, Choung RS, Locke GR 3rd, et al. The incidence, prevalence, and outcomes of patients with gastroparesis in Olmsted County, Minnesota, from 1996 to 2006. Gastroenterology. 2009;136(4):1225-33. https://doi.org/ 10.1053/j.gastro.2008.12.047.

6. Rey E, Choung RS, Schleck CD, Zinsmeister AR, Talley NJ, Locke GR. Prevalence of hidden gastroparesis in the community: the gastroparesis "iceberg.". J Neurogastroenterol Motil. 2012;18(1):34-42. https://doi.org/10. 5056/jnm.2012.18.1.34

7. Coleski R, Baker JR, Hasler WL. Endoscopic gastric food retention in relation to scintigraphic gastric emptying delays and clinical factors. Dig Dis Sci. 2016;61(9):2593-601. https://doi.org/10.1007/s10620-016-4173-7.

8. Knopp H, Halm U, Lamberts R, et al. Incidental and ablation-induced findings during upper gastrointestinal endoscopy in patients after ablation of atrial fibrillation: a retrospective study of 425 patients. Heart Rhythm. 2014;11(4):574-8. https://doi.org/10.1016/j.hrthm.2014.01.010.

9. Choi SW, Kang SH, Kwon OS, et al. A case of severe gastroparesis: indigestion and weight loss after catheter ablation of atrial fibrillation. Pacing Clin Electrophysiol. 2012;35(3):e59-61. https://doi.org/10.1111/j.15408159.2010.02912x

10. Szarka LA, Camilleri M. Gastric emptying. Clin Gastroenterol Hepatol. 2009; 7(8):823-7. https://doi.org/10.1016/j.cgh.2009.04.011.

11. McKenzie P, Bielefeldt K. Glass half empty? Lessons learned about gastroparesis. F1000Res. 2018;7:F1000 Faculty Rev-560. doi: https://doi.org/ 10.12688/f1000research.14043.1

12. Bielefeldt K. Gastroparesis: concepts, controversies, and challenges. Scientifica. 2012;2012:424802. https://doi.org/10.6064/2012/424802.

13. Yamamoto H, Nishi S, Tomo T, et al. 2015 Japanese Society for Dialysis Therapy: Guidelines for Renal Anemia in Chronic Kidney Disease. Renal Replacement Therapy. 2017;3:36. https://doi.org/10.1186/s41100-017-0114-y.

14. Sin FN, Tsang JP, Siu KL, Ma JK, Yung AW. Medications as causes of intraluminal hyperdensities: what radiologists need to know. Eur J Radiol. 2012;81(7):1652-6. https://doi.org/10.1016/j.ejrad.2011.03.010.

15. Bharadwaj S, Meka K, Tandon P, et al. Management of gastroparesisassociated malnutrition. J Dig Dis. 2016;17(5):285-94. https://doi.org/10. 1111/1751-2980.12344

16. Homko CJ, Duffy F, Friedenberg FK, Boden G, Parkman HP. Effect of dietary fat and food consistency on gastroparesis symptoms in patients with gastroparesis. Neurogastroenterol Motil. 2015;27(4):501-8. https://doi.org/10. 1111/nmo.12519.

17. Perlas A, Chan WW, Lupu CM, Mitsakakis N, Hanbidge A. Ultrasound assessment of gastric content and volume. Anesthesiology. 2009;111(1):82 89 doi: https://doi.org/10.1097/ALN.0b013e3181a97250.

18. Van de Putte P, Perlas A. Ultrasound assessment of gastric content and volume. Br J Anaesth. 2014;113(1):12-22. https://doi.org/10.1093/bja/aeu151.

19. Abell TL, Camilleri M, Donohoe $\mathrm{K}$, et al. Consensus recommendations for gastric emptying scintigraphy: a joint report of the American Neurogastroenterology and Motility Society and the Society of Nuclear Medicine. J Nucl Med Technol. 2008;36(1):44-54. https://doi.org/10.2967/ jnmt.107.048116.

20. Ricci DA, Saltzman MB, Meyer C, Callachan C, McCallum RW. Effect of metoclopramide in diabetic gastroparesis. J Clin Gastroenterol. 1985;7:25-32. https://doi.org/10.1097/00004836-198502000-00003.
21. Janssen $\mathrm{P}$, Harris MS, Jones M, Masaoka T, Farré $\mathrm{R}$, Törnblom $\mathrm{H}$, et al. The relation between symptom improvement and gastric emptying in the treatment of diabetic and idiopathic gastroparesis. Am J Gastroenterol. 2013;108(9):1382-91. https://doi.org/10.1038/ajg.2013.118.

22. Olausson EA, Störsrud S, Grundin H, Isaksson M, Attvall S, Simrén M. A small particle size diet reduces upper gastrointestinal symptoms in patients with diabetic gastroparesis: a randomized controlled trial. Am J Gastroenterol. 2014;109(3):375-85. https://doi.org/10.1038/ajg.2013.453.

23. Bielefeldt K, Raza N, Zickmund SL. Different faces of gastroparesis. World J Gastroenterol. 2009;15(48):6052-60. https://doi.org/10.3748/wjg.15.6052.

24. Choung RS, Locke GR 3rd, Schleck CD, et al. Risk of gastroparesis in subjects with type 1 and 2 diabetes in the general population. Am J Gastroenterol. 2012;107:82-8. https://doi.org/10.1038/ajg.2011.310.

25. Huizinga JD. Neural injury, repair, and adaptation in the Gl tract. IV. Pathophysiology of Gl motility related to interstitial cells of Cajal. Am J Physiol. 1998;275(3):G381-6. https://doi.org/10.1152/ajpgi.1998.275.3.G381.

26. Bharucha AE, Batey-Schaefer $B$, Cleary PA, et al. Delayed gastric emptying is associated with early and long-term hyperglycemia in Type 1 diabetes mellitus. Gastroenterology. 2015;149:330-9. https://doi.org/10.1053/j.gastro. 2015.05.007.

27. Gonzalez Z, Loganathan P, Sarosiek I, McCallum RW. Gender-related differences in gastroparesis. Am J Med Sci. 2020;25:S0002-9629(20)30148-8. https://doi.org/10.1016/j.amjms.2020.04.018.

28. Petri M, Singh I, Baker C, Underkofler C, Rasouli N. Diabetic gastroparesis: An overview of pathogenesis, clinical presentation and novel therapies, with a focus on ghrelin receptor agonists. J Diabetes Complications. 2020;6:107733. https://doi.org/10.1016/j.jdiacomp.2020.107733.

29. Krishnasamy S, Abell TL. Diabetic gastroparesis: principles and current trends in management. Diabetes Ther. 2018;9:1-42. https://doi.org/10.1007/s13300018-0454-9.

30. Yolsuriyanwong $\mathrm{K}$, Marcotte $\mathrm{E}$, Venu $\mathrm{M}$, et al. Impact of vagus nerve integrity testing on surgical management in patients with previous operations with potential risk of vagal injury. Surg Endosc. 2019;33:2620-8. https://doi.org/10.1007/s00464-018-6562-9.

31. Niv E, Fireman Z, Vaisman N. Post-pyloric feeding. World J Gastroenterol. 2009;15(11):1281-8. https://doi.org/10.3748/wjg.15.1281.

32. Kim BJ, Kuo B. Gastroparesis and functional dyspepsia: a blurring distinction of pathophysiology and treatment. J Neurogastroenterol Motil. 2019;25(1): 27-35. https://doi.org/10.5056/jnm18162.

33. Masuy I, Van Oudenhove L, Tack J. Review article: treatment options for functional dyspepsia. Aliment Pharmacol Ther. 2019;49(9):1134-72. https:// doi.org/10.1111/apt.15191

34. Pesce M, Cargiolli M, Cassarano S, et al. Diet and functional dyspepsia: clinical correlates and therapeutic perspectives. World J Gastroenterol. 2020; 26(5):456-65. https://doi.org/10.3748/wjg.v26.i5.456.

35. Hasler WL, Parkman HP, Wilson LA, Pasricha PJ, Koch KL, Abell TL, et al. Psychological dysfunction is associated with symptom severity but not disease etiology or degree of gastric retention in patients with gastroparesis. Am J Gastroenterol. 2010;105(11):2357-67. https://doi.org/10. 1038/ajg.2010.253.

36. Karamanolis G, Caenepeel P, Arts J, Tack J. Determinants of symptom pattern in idiopathic severely delayed gastric emptying: gastric emptying rate or proximal stomach dysfunction? Gut. 2007:56(1):29-36. https://doi. org/10.1136/gut.2005.089508.

37. Bredenoord AJ, Chial HJ, Camilleri M, Mullan BP, Murray JA. Gastric accommodation and emptying in evaluation of patients with upper gastrointestinal symptoms. Clin Gastroenterol Hepatol. 2003;1(4):264-72.

38. Azpiroz F, Bouin M, Camilleri M, Mayer EA, Poitras P, Serra J, Spiller RC. Mechanisms of hypersensitivity in IBS and functional disorders. Neurogastroenterol Motil. 2007 Jan;19(1 Suppl):62-88. https://doi.org/10. 1111/j.1365-2982.2006.00875.x.

39. De Schoenmakere G, Vanholder R, Rottey S, Duym P, Lameire N. Relationship between gastric emptying and clinical and biochemical factors in chronic haemodialysis patients. Nephrol Dial Transplant. 2001;16(9):18505. https://doi.org/10.1093/ndt/16.9.1850

40. Funior LD, Santos PR, dos Santos AA, de Souza MH. Dyspepsia and gastric emptying in end-stage renal disease patients on hemodialysis. BMC Nephrol. 2013:14(14):275. https://doi.org/10.1186/1471-2369-14-275.

41. Van Vlem B, Schoonjans R, Vanholder R, et al. Delayed gastric emptying in dyspeptic chronic hemodialysis patients. Am J Kidney Dis. 2000;36(5):962-8. https://doi.org/10.1053/ajkd.2000.19094. 
42. Hirako M, Kamiya T, Misu N, et al. Impaired gastric motility and its relationship to gastrointestinal symptoms in patients with chronic renal failure. J Gastroenterol. 2005;40:1116. https://doi.org/10.1007/s00535-0051709-6.

43. Guz G, Bali M, Poyraz NY, Bagdatoglu O, Yeğin ZA, Doğan I, et al. Gastric emptying in patients on renal replacement therapy. Ren Fail. 2004;26(6): 619-24. https://doi.org/10.1081/jdi-200037167.

44. Dumitrascu DL, Barnert J, Kirschner T, Wienbeck M. Antral emptying of semisolid meal measured by real-time ultrasonography in chronic renal failure. Dig Dis Sci. 1995;40(3):636-44. https://doi.org/10.1007/BF02064384.

45. Soffer EE, Geva B, Helman C, Avni Y, Bar-Meir S. Gastric emptying in chronic renal failure patients on hemodialysis. J Clin Gastroenterol. 1987;9(6):651-3. https://doi.org/10.1097/00004836-198712000-00008.

46. Wright RA, Clemente R, Wathen R. Gastric emptying in patients with chronic renal failure receiving hemodialysis. Arch Intern Med. 1984;144(3):495-6 PMID: 6703819.

47. Kao CH, Hsu YH, Wang SJ. Delayed gastric emptying and Helicobacter pylori infection in patients with chronic renal failure. Eur J Nucl Med. 1995;22(11): 1282-5. https://doi.org/10.1007/BF00801614.

48. Ross EA, Koo LC. Improved nutrition after the detection and treatment of occult gastroparesis in nondiabetic dialysis patients. Am J Kidney Dis. 1998; 31(1):62-6. https://doi.org/10.1053/ajkd.1998.v31.pm9428453.

49. Avram MM, Mittman N, Bonomini L, Chattopadhyay J, Fein P. Markers for survival in dialysis: a seven-year prospective study. Am J Kidney Dis. 1995; 26(1):209-19. https://doi.org/10.1016/0272-6386(95)90176-0.

50. Silang $R$, Regalado $M$, Cheng $T H$, Wesson DE. Prokinetic agents increase plasma albumin in hypoalbuminemic chronic dialysis patients with delayed gastric emptying. Clin Trial Am J Kidney Dis. 2001;37(2):287-93. https://doi. org/10.1053/ajkd.2001.21291.

51. Makari J, Cameron K, Battistella M. Domperidone-associated sudden cardiac death in the general population and implications for use in patients undergoing hemodialysis: a literature review. Can J Hosp Pharm. 2014;67(6): 441-6. https://doi.org/10.4212/cjhp.v67i6.1407.

52. Sewell DD, Jeste DV. Metoclopramide-associated tardive dyskinesia. An analysis of 67 cases. Arch Fam Med. 1992;1(2):271-8. https://doi.org/10.1001/ archfami.1.2.271

53. Sirota RA, Kimmel PL, Trichtinger MD, Diamond BF, Stein HD, Yudis M. Metoclopramide-induced parkinsonism in hemodialysis patients. Report of two cases. Arch Intern Med. 1986;146(10):2070-1 PMID: 3767555.

54. Sewell DD, Yoshinobu BH, Caligiuri MP, Jeste DV. Metoclopramideassociated tardive dyskinesia in hemodialysis patients with diabetes mellitus. Two case reports. Gen Hosp Psychiatry. 1992;14(6):416-9. https://doi.org/10. 1016/0163-8343(92)90009-y.

55. Majanović SK, Zelić M, Belančić A, et al. Gastric electrical stimulation improves symptoms of diabetic gastroparesis in patients on peritoneal dialysis-2 case reports. Dial Int. 2018;38(6):458-62. https://doi.org/10.3747/ pdi.2018.00063.

56. Fountoulakis N, Dunn J, Thomas S, Karalliedde J. Successful management of refractory diabetic gastroparesis with long-term Aprepitant treatment. Diabet Med. 2017;34(10):1483-6. https://doi.org/10.1111/dme.13413.

57. Amin K, Bastani B. Intraperitoneal ondansetron hydrochloride for intractable nausea and vomiting due to diabetic gastroparesis in a patient on peritoneal dialysis. Perit Dial Int. 2002;22(4):539-40 PMID: 12322834.

\section{Publisher's Note}

Springer Nature remains neutral with regard to jurisdictional claims in published maps and institutional affiliations.

Ready to submit your research? Choose BMC and benefit from:

- fast, convenient online submission

- thorough peer review by experienced researchers in your field

- rapid publication on acceptance

- support for research data, including large and complex data types

- gold Open Access which fosters wider collaboration and increased citations

- maximum visibility for your research: over $100 \mathrm{M}$ website views per year

At BMC, research is always in progress.

Learn more biomedcentral.com/submissions 